\title{
Efecto de los contaminantes atmosféricos en el deterioro de aislantes térmicos
}

\section{Effect of pollutant gases on electrical insulators deterioration}

\author{
A.ZAMARAD**,S.MARTÍNEZ-RAMÍREZ ${ }^{*}$, G.E.THOMPSON ${ }^{* *}$, B.E.MOORE**
}

Fecha de recepción: 25-XI-99

(*) Instituto de Ciencias de la Construcción Eduardo Torroja-CSIC.ESPAÑA

Fecha de aceptación: 21-III-00

$\left({ }^{\star *}\right)$ UMIST-Manchester (U.K.)

\section{RESUMEN}

En este trabajo se exponen en cámaras atmosféricas de laboratorio materiales cerámicos usados como aislantes eléctricos. Se realiza un estudio de la superficie expuesta a la degradación medioambiental a través del ángulo de contacto de una gota de agua y de las sales depositadas, determinándose éstas últimas por espectroscopía infrarroja. Los resultados revelan el depósito de varias sales sobre la superficie de la muestra, e hidrólisis sobre la superficie de la resina, modificando el ángulo de contacto.

\section{SUMMARY}

In this work ceramic materials as electrical insulators have been exposed in laboratory-based chambers. Water contact angle and FTIR of the surface before and after pollutant exposures have been studied. The results indicated that the reaction between the policrete and the atmospheric pollutant produce some salts deposits, some hydrolysis over the resin surface, modifying water contact angle.

\section{INTRODUCCIÓN}

Los aislantes se usan en los transmisores eléctricos y en las redes de distribución para soportar, separar o contener los conductores de alto voltaje. Estos aislantes deben presentar buenas propiedades mecánicas con el fin de soportar la carga del conductor. El material aislante debe ser resistente a las condiciones ambientales del lugar en el que se encuentre expuesto; es decir, que un requerimiento adicional que se exige a estos materiales es su durabilidad frente a la agresión medioambiental (1-3).

\section{INTRODUCTION}

Insulators are used on electricity transmission and distribution networks to support, separate, or contain conductors at high voltages. The insulators must exhibit sufficient mechanical properties to support the load of the conductor. This materials must also be insensitive to the ambient conditions at the site of application; thus durability of environmental weathering is an additional requirement (1-3). 
El principal material utilizado en la construcción de aislantes eléctricos es un material cerámico, una porcelana. Sin embargo, hasta el momento, no se ha encontrado ningún compuesto que satisfaga todos los requerimientos exigidos a un buen aislante. Las propiedades deseables en la superficie de los aislantes se consiguen por la cuidadosa selección de los aditivos que permitan controlar la oxidación, la degradación por radiacción UV, la formación de grietas, permeabilidad, etc.

De entre los aditivos añadidos podemos destacar, como estabilizadores de la radiación UV: $\mathrm{TiO}_{2}, \mathrm{Fe}_{2} \mathrm{O}_{3}$ o $\mathrm{ZnO}$, la utilización de uno u otro dependerá de su coste, color y compatibilidad con el material base. Como antioxidantes se usan aditivos orgánicos como fenoles o aminas. Entre los agentes antigrietas se incluyen $\mathrm{Mg}(\mathrm{OH})_{2}$ y $\mathrm{CaCO}_{3}(4,5)$. El tipo de árido utilizado así como la técnica de procesado de los materiales, son factores que también se tienen que tener en cuenta a la hora de conseguir que los materiales alcancen la vida en servicio deseada (6).

La degradación medioambiental de los materiales poliméricos usados como aislantes se asocia con las transformaciones moleculares que en ellos se pueden producir. Esta degradación se origina por la interacción entre el medioambiente y la estructura química particular de cada polímero. Los factores medioambientales que influyen en la degradación de estos materiales aislantes incluyen: radiación solar, humedad, calor, contaminantes, etc.

El aislante es de gran importancia en una estación eléctrica desde el punto de vista de la continuidad del servicio. La mayoría de los problemas de los equipos se deben a fallos en el aislante. Por ello es de vital importancia la selección del material aislante adecuado, tanto desde el punto de vista del diseño, como del control de los agentes externos destructores.

En este trabajo vamos a estudiar el efecto de los contaminantes atmosféricos en el deterioro de los materiales utilizados como aislantes térmicos.

\section{EXPERIMENTAL}

\section{Materiales y métodos}

El material que vamos a estudiar se denomina policrete y está compuesto de $82 \%$ en peso de árido y $18 \%$ en peso de resina de poliéster con aditivos. Los fabricantes del policrete no suministraron detalles de la composición de la resina por razones comerciales. A través de espectroscopía infarroja se reveló la presencia de $\mathrm{Al}(\mathrm{OH})_{3}$ (añadido para evitar que se
The principal material used for the construction of insulators is electrical porcelain, a ceramic.

However, until now, no single compound has been found to satisfy all the surface requirements of good insulation. The desired surface properties result from the careful selection of additives that control oxidation, UV degradation, tracking and wetting.

Additives include $\mathrm{UV}$ stabilisers; normally $\mathrm{TiO}_{2}$, $\mathrm{Fe}_{2} \mathrm{O}_{3}$ or $\mathrm{ZnO}$, depending on the cost, colour and compatibility with base material. Some organic compounds such as phenols and amins are used as anti-oxidants. Anti-craking agents include, $\mathrm{Mg}(\mathrm{OH})_{2}$ and $\mathrm{CaCO}_{3}$ (4,5). The type of fillers loading and processing techniques are important factors in achieving the desired service life (6).

The environmental degradation of a polymeric insulating material is associated with molecular transformations. These are the result of interactions between the environmental and the particular chemical structure of each polymer. Changes in the chemical structure often lead to a reduction in the electrical resistance. The environmental factors that influence the degradation of an insulating material include: solar radiation, moisture, heat, pollutants, salt water, etc.

The insulation of an electrical power system is of critical importance from the standpoint of service continuity. Most major troubles are traceable to insulation failure. Thus, the proper selection of the insulating material, correct insulator profile and dimensions, and control of destructive agents is of critical importance.

In this work we are going to study the effect of pollutants in the degradation of this insulators materials.

\section{EXPERIMENTAL}

\section{Materials and methods}

The insulator used is named polycrete. Polycrete is composed of $82 \%$ by weight of sand, $18 \%$ by weight of a polyester resin and additive compounds. The manufactures of polycrete did not supply detailed information on the composition of the resin for reasons of commercial sensitivity. IR analysis of polycrete reveals $\mathrm{Al}(\mathrm{OH})_{3}$ presence, which is added as 
produzcan arcos eléctricos), así como la presencia de grupos $-\mathrm{CH}_{3}-\mathrm{CO}-\mathrm{OR}$ - de la resina y de sílice adicionada como árido.

Se realizó una exposición de los materiales en las cámaras de simulación de ambientes agresivos. Las condiciones de exposición, de acuerdo a estudios previos $(7,8)$, fueron las que se consideran más agresivas. El policrete se expuso en la cámara bajo 4 condiciones diferentes, a saber: an arcing agent; groups $-\mathrm{CH}_{3}-\mathrm{CO}-\mathrm{OR}$-from the polyester in the polycrete and silica added as sand.

The samples were exposed in the laboratory-based chambers with the greatest aggressive medium, according to previous papers $(7,8)$. In total 4 dry deposition exposures were carried out on polycrete:

(i) $10 \mathrm{ppm} \mathrm{SO}_{2}+10 \mathrm{ppm} \mathrm{NO}_{2}+10 \mathrm{ppm} \mathrm{NO}$

(ii) $10 \mathrm{ppm} \mathrm{SO}+10 \mathrm{ppm} \mathrm{NO}+10 \mathrm{ppm} \mathrm{NO}+10 \mathrm{ppm} \mathrm{O}_{3}$

(iii) $10 \mathrm{ppm} \mathrm{SO}+10 \mathrm{ppm} \mathrm{NO}+10 \mathrm{ppm} \mathrm{NO}+\mathrm{H}_{2} \mathrm{O}$

(iv) $10 \mathrm{ppm} \mathrm{SO}+10 \mathrm{ppm} \mathrm{NO}_{2}+10 \mathrm{ppm} \mathrm{NO}+10 \mathrm{ppm} \mathrm{O}_{3}+\mathrm{H}_{2} \mathrm{O}$

Se expusieron 10 muestras por cámara.

La velocidad de interacción de los contaminantes con los materiales expuestos en las cámaras en relación a la concentración de los mismos se presenta en la Tabla I. Cada exposición duró 30 días; las condiciones de exposición son las mismas que las indicadas en publicaciones anteriores (8).

La medida del ángulo de contacto de una gota de agua es una técnica barata que es sensible a la composición química superficial. Esta medida es muy utilizada en los aislantes para determinar su resistencia a la formación de una capa de agua superficial (9). Una gota de agua desionizada de $10 \mu \mathrm{l}$ se deposita sobre la superficie del material usando un dosificador adecuado. La gota se registra con una cámara de vídeo que permite aumentar la imagen x 40. Una imagen de la gota al minuto de
Ten samples in each chamber were exposed. The presentation rates for the pollutants in the exposures runs are given in Table I. Each exposure lasted for 30 days and the exposure conditions have been described previously (8).

The contact angle is relatively simple, inexpensive technique, that is sensitive to the chemical composition of the surface layer. Contact angle measurements are widely used to determine the ability of an insulator material to resist the formation of water films on the surface (9). A $10 \mu$ droplet of desionised water is delivered to the surface of the material using a specially modified dropper. The droplet is imaged using a video camera fitted with a across lens so that an image at $x 40$

TABLA I/TABLE I

Concentración y velocidad de interacción de los contaminantes

Pollutant concentration and presentation rates

\begin{tabular}{|l|l|l|}
\hline $\begin{array}{l}\text { Contaminante } \\
\text { Pollutant }\end{array}$ & $\begin{array}{l}\text { Concentración } \\
\text { contaminante } \\
\text { Pollutant concentration }(p p m)\end{array}$ & $\begin{array}{l}\text { Velocidad de interacción } \\
\text { Presentation rate } \\
\left(\mu \mathrm{g} \mathrm{m}^{2} \mathrm{~s}^{-1}\right)\end{array}$ \\
\hline & & \\
$\mathrm{SO}_{2}$ & 10 & 162 \\
$\mathrm{NO}_{2}$ & 10 & 80 \\
$\mathrm{NO}$ & 10 & 74 \\
\hline
\end{tabular}


haberla depositado sobre la muestra se imprime y sobre ella se realiza la medida del ángulo de contacto.

El valor del ángulo de contacto medido en el policrete antes de exponerlo en la cámara tiene un valor de $\theta=76^{\circ} \pm 6$. La variación en el ángulo de contacto $\left(\theta= \pm 6^{\circ}\right)$ se debe a la heterogeneidad y rugosidad de la superficie, debido a la presencia de regiones de alta y baja energía procedentes de la resina y de la sílice respectivamente.

\section{RESULTADOS Y DISCUSIÓN}

\section{Estudio a través de espectroscopía infrarroja}

El espectro IR del policrete expuesto en la cámara con adición de $\mathrm{SO}_{2}+\mathrm{NO}_{2}+\mathrm{NO}$ muestra la aparición de bandas nuevas con respecto al del material antes de la exposición (Figura 1). Las muestras expuestas en todas las condiciones presentan un pico agudo a $1.384 \mathrm{~cm}^{-1}$ y un pequeño pico a $840 \mathrm{~cm}^{-1}$ debidos a las vibraciones de los grupos $\mathrm{NO}_{3}^{-}$, indicando la formación de nitratos sobre la superficie de las muestras. No es posible discernir si los nitratos están químicamente unidos a la resina; o si por el contrario están unidos al aditivo, ya que ambos vibran en las mismas regiones, lo que no nos permite discernir si el ataque del contaminante es a la resina o al aditivo. En el caso de las muestras expuestas en la cámara con adición de agua, se observa la aparición de un pico agudo a $1.630 \mathrm{~cm}^{-1}$ debido a la vibración de grupos $\mathrm{OH}$. Junto a esto se produce una disminución en las bandas a 1.728 y $1.284 \mathrm{~cm}^{-1}$ de las vibraciones de los grupos $\mathrm{C}=\mathrm{O}$ y $\mathrm{C}-\mathrm{O}-\mathrm{C}$ respectivamente. Esto sugiere que se está produciendo una hidrólisis en la resina: magnification is obtained. A hard copy of this image 1 minute after placement using a video printer, enabling the contact angle to be measured to manually.

Contact angle measurements on unexposed polycrete gave an average value of $\theta=76^{\circ} \pm 6$. The variation in the contact angle was due to the heterogeneity and roughness of the surface. The heterogeneity of the surface is due to high and low surface energy regions, which arise from the resine and silica components of the material respectively.

\section{RESULTS AND DISCUSSION}

\section{Infrared analysis results}

The IR spectra of the polycrete subjected to the dry deposition of $\mathrm{SO}_{2}+\mathrm{NO}_{2}+\mathrm{NO}$ pollutant gases revealed the appearance of new peaks (Figure 1). All the samples exposed to the pollutant exhibit narrow new peaks at $1.384 \mathrm{~cm}^{-1}$ and smaller peaks at $840 \mathrm{~cm}^{-1}$; these vibrations arise from $\mathrm{NO}_{3}^{-}$indicating the presence of nitrate over the surface of the samples. It is not possible to ascertain whether the nitrate is chemically bonded to the polyester resin, or bonded with one of the additive compounds, since both nitrate absorb in the same regions. For this reason is difficult to know if the pollutant react with resin or with the additive. Additionally for wetted exposure samples a small additional peak at $1.631 \mathrm{~cm}^{-1}$, which arises from $\mathrm{OH}$ bending vibrations. This peak is coupled simultaneously with large decreases in the peaks at 1.728 and $1.284 \mathrm{~cm}^{-1}$, the $C=O$ and $C-O-C$ vibrations respectively. The decrease in the ester vibrations and the corresponding increase in the $\mathrm{OH}$ vibrations suggested that hydrolysis of the polyester resin is occurring:

$$
-\mathrm{CH}_{3}-\mathrm{CO}-\mathrm{OR}-+\mathrm{H}^{+} \rightarrow \mathrm{CH}_{3}-\mathrm{COOH}+\mathrm{R}-
$$

Sólo se observa la aparición de una banda en la región de $1.100 \mathrm{~cm}^{-1}$ debida a la vibración de los grupos $\mathrm{SO}_{4}{ }^{2-}$, para las muestras expuestas en presencia de ozono. Esto indica que sobre la superficie de las muestras se forman dos tipos de sales, nitratos y sulfatos. Los nitratos se forman en todos los casos y los sulfatos únicamente en presencia de ozono.

Los cuatro picos que aparecen en la zona 3.200-3.600 $\mathrm{cm}^{-1}$ provienen de las tensiones de vibración de los grupos $\mathrm{OH} \operatorname{del~} \mathrm{Al}(\mathrm{OH})_{3}$.

El ensanchamiento de la banda observado cuando sobre las muestras se adiciona agua (Figura 1), confirmaría la hidrólisis de la resina de acuerdo a la reacción [1].
However, only both samples under ozone exposure shows increases in absorption at $1.110 \mathrm{~cm}^{-1}$ where the $S-O$ vibration in sulphate occurs. This indicated that over the surface of the sample two types of salts, nitrates and sulphates, have been deposited. The nitrates are deposited after every exposure, but sulphates only are present under ozone presence.

The four clearly resolved peaks from 3.200 to $3.600 \mathrm{~cm}^{-1}$ originated from $\mathrm{OH}$ stretching vibrations from $\mathrm{Al}(\mathrm{OH})_{3}$.

The broadness of the band observed in the samples with water addition (Figure 1), confirm the hydrolysis of the polyester resin according to equation [1]. 


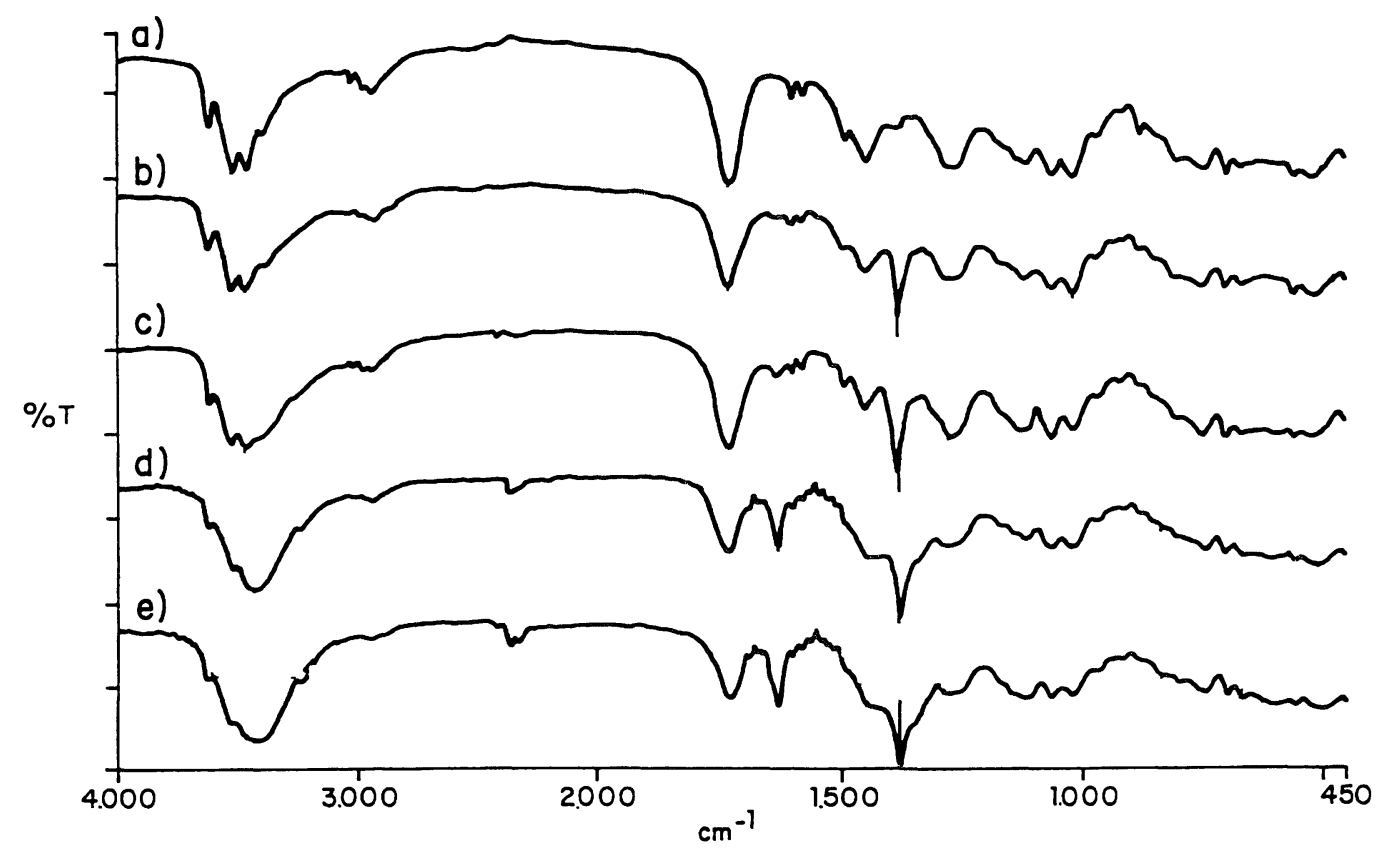

Figura 1.- Infrarrojo del policrete antes y después de exponerlo en las diferentes cámaras. a) muestra antes de la exposición; b) $10 \mathrm{ppm} \mathrm{SO} \mathrm{SO}_{2}+10 \mathrm{ppm} \mathrm{NO}_{2}+10 \mathrm{ppm} \mathrm{NO}$; ) $10 \mathrm{ppm} \mathrm{SO}_{2}+10 \mathrm{ppm} \mathrm{NO}_{2}+10 \mathrm{ppm} \mathrm{O}_{3}$; d) $10 \mathrm{ppm} \mathrm{SO}_{2}+10 \mathrm{ppm} \mathrm{NO}_{2}+10 \mathrm{ppm} \mathrm{NO}$ $+\mathrm{H}_{2} \mathrm{O}$; e) $10 \mathrm{ppm} \mathrm{SO}_{2}+10 \mathrm{ppm} \mathrm{NO}_{2}+10 \mathrm{ppm} \mathrm{NO}+10 \mathrm{ppm} \mathrm{O}_{3}+\mathrm{H}_{2} \mathrm{O}$

Figure 1.- Infrared of the poliycrete before and after de exposure in the chambers. a) sample before the exposition; b) 10 ppm $\mathrm{SO}_{2}+10 \mathrm{ppm} \mathrm{NO} \mathrm{N}_{2}+10 \mathrm{ppm} \mathrm{NO}$; c) $10 \mathrm{ppm} \mathrm{SO}_{2}+10 \mathrm{ppm} \mathrm{NO}_{2}+10 \mathrm{ppm} \mathrm{O}_{3}$; d) $10 \mathrm{ppm} \mathrm{SO}_{2}+10 \mathrm{ppm} \mathrm{NO}_{2}+10 \mathrm{ppm} \mathrm{NO}+$ $\mathrm{H}_{2} \mathrm{O}$; e) $10 \mathrm{ppm} \mathrm{SO}_{2}+10 \mathrm{ppm} \mathrm{NO} \mathrm{N}_{2}+10 \mathrm{ppm} \mathrm{NO}+10 \mathrm{ppm} \mathrm{O}_{3}+\mathrm{H}_{2} \mathrm{O}$

\section{Ángulo de contacto de una gota de agua}

El valor medio del ángulo de contacto del policrete antes de la exposición en las cámaras es de $\theta=76^{\circ} \pm 6^{\circ}$. Se determinó el ángulo de contacto después de la exposición en las cámaras, con el fin de valorar los cambios experimentados por las muestras. En general se observó una disminución del ángulo de contacto con respecto al valor antes de la exposición (Tabla II). Ordenando los valores de mayor a menor tenemos el siguiente orden:

\section{Water contact angle}

The average contact angle on clean unexposed polycrete was $\theta=76^{\circ} \pm 6^{\circ}$. Measurements were carried out on exposed polycrete, from both exposure runs, to asses if any changes in the contact angle occurred as a result of exposure. According to the value for the unexposed sample, decreases in the contact angle were observed (Table II). Measurements on polycrete exposed to $\mathrm{SO}_{2}+\mathrm{NO}_{2}+\mathrm{NO}$ pollutant gases reveal larger decreases in the contact angle, with the order:

$$
\mathrm{SO}_{2}+\mathrm{NO}_{2}+\mathrm{NO}<\mathrm{SO}_{2}+\mathrm{NO}_{2}+\mathrm{NO}+\mathrm{H}_{2} \mathrm{O}<\mathrm{SO}_{2}+\mathrm{NO}_{2}+\mathrm{NO}+\mathrm{O}_{3}=\mathrm{SO}_{2}+\mathrm{NO}_{2}+\mathrm{NO}+\mathrm{O}_{3}+\mathrm{H}_{2} \mathrm{O}
$$

Para estudiar el efecto del ozono comparamos los valores de las cámaras i) y ii) con iii) y iv) respectivamente, observándose que en presencia de ozono se reduce el ángulo de contacto con respecto a las cámaras sin adición de oxidante. Como ya hemos indicado anteriormente, el ángulo de contacto del agua superficial depende de las reacciones químicas que se produzcan sobre la superficie de la muestra. A través de IR hemos visto que una cierta cantidad de nitratos y sulfatos se han formado sobre la superficie de las
To study the effect of ozone in the water contact angle values for the samples exposed in chambers i) and ii) were compared with the values in the chambers iii) and iv) respectively have been done. In exposures, the presence of $\mathrm{O}_{3}$ led to greater decreases in the contact angle. As indicated previously, the surface water contact angle is influenced by the chemistry of the surface. From FTIR results, relatively large quantities of retained sulphate and nitrate were found on polycrete 
Ángulo de contacto de una gota de agua medido para el policrete antes y después de exponerlo en las cámaras

Water contact angle measurements for polycrete before and after exposure

\begin{tabular}{|l|l|l|}
\hline $\begin{array}{l}\text { Cámara } \\
\text { Chamber }\end{array}$ & $\begin{array}{l}\theta\left(^{\circ}\right) \text { Antes de la } \\
\text { exposición } \\
\text { Before exposure }\end{array}$ & $\begin{array}{l}\theta\left(^{\circ}\right) \text { Después de la } \\
\text { exposición } \\
\text { After exposure }\end{array}$ \\
\hline $\mathrm{SO}_{2}+\mathrm{NO}_{2}+\mathrm{NO}$ & $76 \pm 6$ & $74 \pm 3$ \\
$\mathrm{SO}_{2}+\mathrm{NO}_{2}+\mathrm{NO}+\mathrm{H}_{2} \mathrm{O}$ & $76 \pm 6$ & $75 \pm 12$ \\
$\mathrm{SO}_{2}+\mathrm{NO}_{2}+\mathrm{NO}+\mathrm{O}_{3}$ & $76 \pm 6$ & $66 \pm 5$ \\
$\mathrm{SO}_{2}+\mathrm{NO}_{2}+\mathrm{NO}+\mathrm{O}_{3}+\mathrm{H}_{2} \mathrm{O}$ & $76 \pm 6$ & $66 \pm 14$ \\
\hline
\end{tabular}

muestras expuestas en las cámaras con adición de $\mathrm{SO}_{2}+\mathrm{NO}_{2}+\mathrm{NO}$. La presencia de estos iones sobre la superficie produce un aumento de la energía superficial, lo que origina una disminución del ángulo de contacto.

Se observa que en presencia de agua la dispersión de los valores del ángulo de contacto $(\theta= \pm 12, \pm 14)$ es superior a cuando no se adiciona agua al medio $(\theta= \pm 3, \pm 5)$. La hidrólisis producida sobre la superficie de la resina puede justificar la dispersión de los valores.

\section{CONCLUSIONES}

El resultado de los cambios físicos y químicos hacen la superficie del material polimérico más hidrófila, favoreciendo la formación de una capa de agua, que produce la disolución del contaminante y el posterior deterioro del policrete.

\section{AGRADECIMIENTOS}

Los autores quieren agradecer a EA Technology por subvencionar la investigación. También se quiere agradecer a la Dirección General de Investigación Científica y Técnica (MEC) por la beca postdoctoral concedida a uno de sus autores (SMR). exposed to the dry deposition of $\mathrm{SO}_{2}+\mathrm{NO}_{2}+\mathrm{NO}$. The increase in retained anions lead to increases in the surface energy and thus falls in the surface water contact angle.

Wetted samples exhibited a larger range $(\theta= \pm 12, \pm$ 14) of contact angle values than unwetted ( $\theta= \pm 3, \pm 5)$ samples. The hydrolysis produce over the surface of the resin can justify the large range of the water contact angle under wetted conditions.

\section{CONCLUSIONS}

The net result of the physical and chemical changes of the material is making the surface more hydrophilic, thereby favouring the formation of water films, which leads to increased pollutant dissolution and thereby polycrete deterioration.

\section{ACKNOWLEDGEMENTS}

The authors wish to thanks to EA Technology for the support of the research. We also are grateful to the Spanish Dirección General de Investigación Cientifica y Técnica (MEC) for the grant give to one of the authors (SMR).

\section{BIBLIOGRAFÍA}

1.- Looms, J.S.T. "Insulators for High Voltages", Peregrinus on behalf of Electrical Engineers, London, 1988.

2.-Ulhmann, E. "Power Transmission by Direct Current", Springer-Verlag, 1975.

3.-Cotton, H. "The transmission and Distribution of Electrical Energy". 3rd Edition. Hodder and Stoughton, 1978.

4.-Parr, D.J., Scarisbrick, R.M. "Peformance of synthetic insulating materials under polluted conditions". Proceedings of IEE. Vol. 112, No8, august, 1965 .

5.-Gorur, R.S., Chang, J. "AC clean fog test on non-ceramic insulating materials and a comparison with porcelain". IEEE Transctions on Power Delivery, Vol.9, №4, october 1994." 
6.-Deng, H. Hackman R. Electrical Performance in Salt-Fog of XLPE Containing Different Levels of $\mathrm{CaCO}_{3}$ Filler". IEEE Conference on Electrical Insulation of Dielectric Phenomena-94, CH3456-1, pp.553-558, 1994.

7.- Haneef, S.J., Johnson, J.B., Dickinson, C., Thomspon, G.E. and Wood, G.C. "Effect of dry deposition of $\mathrm{NO}_{x}$ and $\mathrm{SO}_{2}$ gaseous pollutants o the degradation of calcareous building stones". Atmospheric Environment, Vol.26A, No16, pp.2963-2974, 1992.

8.- S. Martinez-Ramirez and A. Zamarad. "Organic and inorganic concrete under $\mathrm{SO}_{2}$ pollutant exposure". Building and Environment (Aceptado 2000).

9.-Mu Shik Jhon and Soon Hong Yuk. "Contact angles at polymer-water interface; temperature dependence and the induced deformation". Polymer Surface Dynamics, Andare J., 1992.

\section{$* * *$}

\section{IN MEMORIAM}

\section{Dra. Ángeles Vicente Hernández}

María Ángeles Vicente Hernández, miembro del Comité de Redacción de la revista MATERIALES DE CONSTRUCCIÓN e Investigador Científico del CSIC, falleció, de forma repentina e inesperada, el día 28 de abril de 2000 .

La Dra. Vicente Hernández realizó sus estudios de Licenciatura en Ciencias Químicas en la Facultad de Ciencias de la Universidad de Salamanca; su actividad en el Centro de Edafología de Salamanca, actualmente Instituto de Recursos Naturales y Agrobiología(IRNASA), comienza en el año 1965 como Becaria del CSIC, realizando su Tesis Doctoral sobre "Estudio de arcillas cerámicas de la Provincia de Salamanca", iniciando así su formación en el campo de la Mineralogía de Arcillas en el que, abordando diferentes aspectos, trabajará durante toda su actividad investigadora. Su formación en este campo la completa con una estancia postdoctoral de tres años en la "Station de Science du Sol" del Centre National des Recherches Agronomiques (INRA, Versalles, Francia), investigando fundamentalmente la alteración de rocas y minerales de la arcilla por ácidos orgánicos y estableciendo durante su estancia unas relaciones con científicos del INRA, que, posteriormente, se plasmaron en una colaboración ininterrumpida en diversos proyectos conjuntos de investigación, estancias, etc., en ése y otros centros de investigación europeos.

En 1982, y partiendo de sus amplios conocimientos sobre mineralogía de arcillas y alteración de rocas, inicia una interesante línea de investigación sobre "Procesos de Alteración y Conservación de Rocas Ornamentales de Edificios Históricos", en la que se vuelca con su característico entusiasmo, siendo una de las pioneras que en España trabajaron en este campo. Proyectos de investigación de ámbito regional, nacional e incluso subvencionados desde la Unión Europea, organización de congresos, conferencias, aparte de numerosas publicaciones científicas y participación también en actividades de divulgación, han sido algunas de las líneas en que se movió en los últimos veinte años, formando a su alrededor un grupo de investigación interdisciplinar, entendiendo que era la única forma de abordar con rigor los estudios de alteración y conservación citados. Toda esta labor cristalizó hace cuatro años en la creación de una "Unidad Asociada de Investigación" entre el IRNASA y la Universidad de Salamanca. Debe destacarse que nunca abandonó sus actividades docentes (quizá por una arraigada tradición familiar), en la enseñanza secundaria, en la Universidad y participando en cursos de Tercer Ciclo durante más de una década en la Universidad de Salamanca y otras, así como en otros cursos de postgrado.

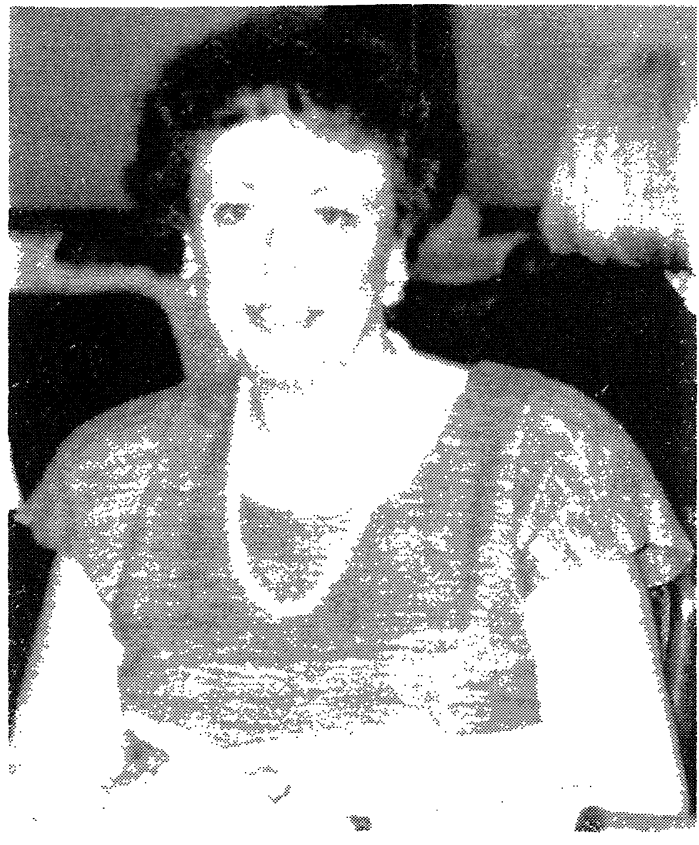

$\mathrm{M}^{\mathrm{a}}$ Ángeles formaba parte del Comité de Redacción de MATERIALES DE CONSTRUCCIÓN, desde 1995. Durante todo este tiempo dio muestras constantes de dedicación y trabajo en pro de potenciar e impulsar la revista en todos aquellos ámbitos en los que ella se encontraba, aparte de participar directamente en las funciones propias del Comité.

Su carácter extrovertido, su generosidad y su conversación amena le granjearon el afecto y simpatía de todos los compañeros del IRNASA y cuantas personas contactaron con ella en el desarrollo de sus actividades, como todos los miembros del Comité de Redacción. $\mathrm{M}^{\mathrm{a}}$ Ángeles deja, sin duda, un vacío humano y científico en el Instituto y en todas las personas que la conocieron y su recuerdo perdurará entre nosotros.

Todos los miembros del Comité de Redacción de la revista de MATERIALES DE CONSTRUCCIÓN se unen al pesar por la pérdida de $\mathrm{M}^{\mathrm{a}}$ Ángeles.

IRNA de Salamanca (CSIC) Unidad Asociada (IRNASA-Universidad de Salamanca) Comité de Redacción de "Materiales de Construcción" 